International Journal of English Literature and Social Sciences
Vol-6, Issue-5; Sep-Oct, 2021

Peer-Reviewed Journal

\title{
Juxtaposing the Realistic and the Speculative Elements in Haruki Murakami's Kafka on the Shore
}

\author{
Rameez Ahmad Bhat
}

\author{
Research Scholar, Dept of English, Aligarh Muslim University, India \\ ramizamu2012@gmail.com \\ OrcId: https://orcid.org/my-orcid?orcid=0000-0001-7513-7210
}

Received: 04 Sep 2021; Received in revised form: 28 Sep 2021; Accepted: 06 Oct 2021; Available online: 16 Oct 2021 (C)2021 The Author(s). Published by Infogain Publication. This is an open access article under the CC BY license (https://creativecommons.org/licenses/by/4.0/).

\begin{abstract}
In contrast to a study by Virginia Yeung of Haruki Murakami's novel 1Q84, by analysing how it has "manipulated embedding to strengthen his themes and to create a complex novel world", this paper discusses the realistic and the speculative elements in his Kafka on the Shore (426). Itattempts to pinpoint in the novelthe elements or "spots of time", as it were, where the demarcation between what is real and what is magical fades away (Wordsworth 208-18). Adding to her conclusion of Julie Wittes Schlack's review of the novel, she suggests that "Murakami creates a magical reality in which past and present, dreams and reality merge like the sides of a Mbius strip". However, in this book, Murakami expands his reach by dipping into Greek mythology, personal and national identity, Christianity, and literary criticism". The article also demonstrateshow the blending or mixing of the two genres, the realistic and the magical, provides the main characters with new perspectives fortheir lives, the people they encounter, and the world they inhabit (2005).
\end{abstract}

Keywords - Dreams, interplay, magical realism, Realist fiction, speculative fiction.

It has become commonplace in our multicultural world more than ever to come across or engage perspectives or worldviews radically different from our own. Gone are the days when we had at our disposal only a single perspective. Instead, we have a countless web of these circulating about through different media, including literature. From Beowulf to Virginia Woolf and up to our times, literature has played a vital role in integrating and giving space to worldviews different from the established ones. Often it would be cast as insignificant, hence, not meant for serious study. However, just after the end of the Second World War, we see venturing into mainstream literature new genres - speculative literature, fiction in particular, such as fantasy, Sci-Fi, magic realism.

Magical realism has been used in two senses, one narrower and the other broader. The former points to a kind of writing where both the elements of the realistic and the magical exist, and the latter "seeks to engage not only with a history of textual representation, but also with the implications and the categories that underpin that representation" (Warnes \& Sasser, 2020). According to Cuddon (1998), the characteristic features of magic realism are: "the mingling and juxtaposition of the realistic and the fantastic or bizarre; skilful time shifts; convoluted and even labyrinthine narratives and plots; miscellaneous use of dreams, myths and fairy stories; expressionistic and even surrealistic description; arcane erudition; the element of surprise or abrupt shock; and the horrific and the inexplicable" (p. 488). As Gioia opines about Murakami, "few writers have poked more holes in conventional notions of reality than the Japanese novelist Haruki Murakami” (p. 01). However, one of the first and the core aspects, the mingling of the realistic and the fantastic, can be observed from the beginning of the novel. A detailed description follows of what is happening in the mind of Kafka Tamura, the main protagonist, and the commentary of a "boy named 
Crow", haunting him throughout the"run away" plan; Crow describes that on my fifteenth birthday, I would run away from home, travel to a far-away town, and live in a corner of a small library (Murakami, 2003, p. 05).Presented with a picture of Kafka's long desire of leaving his home, the historical events of World War Two Japan and theRice Bowl Hill Incident,which will have a disastrous effect on several characters in the novel, not only are we given the bizarre and fantastic details of the commentary of a "Crow" but also, in the case of Nakata, the unusual but philosophical analysis on the anthropocentric world by cats. For instance, the commentary of the boy named Crow repeatedly appear in bold-faced:

Sometimes fate is like a small sandstorm that keeps changing directions. You change direction but the sandstorm chases you. You turn again, but the storm adjusts. Over and over you play this out, like some ominous dance with death just before dawn. Why? Because this storm isn't something that blew in from far away, something that has nothing to do with you. This storm is you. Something inside of you. So all you can do is give in to it, step right inside the storm, closing your eyes and plugging up your ears so the sand doesn't get in, and walk through it, step by step. There's no sun there, no moon, no direction, no sense of time. Just fine white sand swirling up into the sky like pulverised bones. That's the kind of sandstorm you need to imagine. (original bold, Murakami, 2003,p. 04)

Countless examples, such as these abound inthe novel. Moreover, imperialistic Japan, its policies and the attendant fatal consequences, with its American domination is explained throughout the novel. Two examples of each one of the modes can be enough to make the point. In an interview,Doctor JuichiNakazawa ran a medical clinic then, describes the whole Rice Bowl Hill Incident in vivid detail:

This incident never made the newspapers. My guess is the authorities decided it would only cause unrest, so they banned any mention of it. You have to remember that during the war the military tried to squelch whatever they saw as groundless rumours. The war wasn't going well, with the military retreating on the southern front, suicide attacks one after the other, air raids on cities getting worse all the time. The military was especially afraid of any anti-war or pacifist sentiment cropping up among the populace. A few days after the incident the police came calling and warned us that under no circumstances were we to talk about what we'd seen. (Murakami, 2003, p. 37)

From the narrative point of view, there is a mixture of both methods. A realistic detail describes events not otherwise given to render words, letters, newspaper reporting of events, dreams. According toSorensen (2007), the core structural motif of magical realism is"the transformation of the real (ice, for instance, at the beginning of the novel) into the unreal, and the magical (the rain of yellow flowers, levitation, magic carpets) into the natural" (p. 57). The transformation the author talks about can perhaps be perceived at several places in the novel, for instance, when "leeches rained down hard for a time, then tapered off and stopped" (Murakami, 2003,p. 255). In the first instance before this incident, something unusual happened already out of sync with reality thus:

The next day when - sure enough — sardines and mackerel rained down on a section of Nakano Ward, the young policeman turned white as a sheet. With no warning whatsoever some two thousand sardines and mackerel plunged to earth from the clouds. Most of the fish were crushed to a pulp as they slammed into the ground, but a few survived and flopped around on the road in front of the shopping district. The fish were fresh, still with a smell of the sea about them. The fish struck people, cars, and roofs, but not, apparently, from a great height, so no serious injuries resulted. It was more shocking than anything else. A huge number of fish falling like hail from the sky-it was positively apocalyptic. (Murakami, 2003, p. 221)

Beyond the world of historical facts and events in the novel lies the worlds of dreams and supernatural, juxtaposing the two time and again. The incorporation in the novel of the latter foregrounds the idea that there is more to what the realistic mode of writing could encompass, as Hamlet would say, "there are more things in heaven and earth, Horatio, than are dreamt of in your philosophy" (Shakespeare, 2010, p. 167-8).Thus, argues Gioia (n.d) in reviewing the novel, that "like magician David Copperfield making the Statue of Liberty disappear (or at least seem to disappear), Murakami mesmerises us by working his legerdemain in places where reality would seem to be rock solid".

The use of dreams plays a central role in the novel. Sometimes, as some writers say about it, it seems that the whole novel is a dream (Meads, Shepard). Dreams provide the characters with the sense of having a goal in life. Moreover, it provides them with the place to think 
over things which would otherwise be impossible to do in real life. Replying to a question on his website as to the reason behind his drive to the realm of the dreamlike, Murakami (2021) replies thus:

Norwegian Wood is, as you've said, the only one written in a realistic style. I did this intentionally, of course. I wanted to prove to myself that I could write a $100 \%$ realistic novel. And I think this experiment proved helpful later on. I gained the confidence I could write this way; otherwise it would have been pretty hard to complete the work that came afterwards. For me, writing a novel is like having a dream. Writing a novel lets me intentionally dream while I'm still awake. I can continue yesterday's dream today, something you can't normally do in everyday life. It's also a way of descending deep into my own consciousness. So while I see it as dreamlike, it's not fantasy. For me the dreamlike is very real.

Several instances from the novel could be appended in support of the above given thought. For example, in a letter to a Professor, Setsuko Okamochi, the teacher in charge of the students to a trip towhere Rice Bowl Hill Incident in 1944happened, describes how dreams help her to fulfil what in real life she could not imagine doing as:

It's strange, now that I think of it, for in real life the two of us were quiet, rather introverted people. We'd never given in to our passions like this or experienced such soaring pleasure. But in the dream, for the first time in our lives, we'd thrown away all restraints and were going at it like animals. (Murakami, 2003, p. 128)

Moreover, in a conversation with Oshima after he got to know about his father's death in a newspaper, Kafka began to understand heis the one who has killed his own father"through a dream ... through some special dream circuit or something and killed him" (p. 268).

The use of shifting of timeframes in the novel is conspicuous. At first, what appears to be a linear progression of the plot(s) becomes blurred over time. We are led to stories in the present and to the ones in the past.This shifting of timeframes from the present to the past, traumatic or otherwise, enacts itself whenever the main characters come across something or someone. For instance, going through every item of his house, and coming across a childhood photo of he and his sister, Kafka points to that period of their time together on a beach somewhere he does not know for sure (Murakami, 2003,p. 07).The very first chapter of the novel details the escaping plan and the essentials Kafka might need throughout the journey. On his fifteenth birthday, Kafka narrates, he would leave his father's house and never return back.

The narrative often touches upon World War Two Japan and its consequences on the present-day Japan. The second chapter of the novel opens with an interview of one of the witness-survivors, Setsuko Okamochi, of Rice Bowl Hill Incident in 1944 during the Bomb attack. She describes the whole incident to the interviewer, for example, from the number of students to the very moment she lost her consciousness when the bomb fell (Murakami, 2003, p. 12).

The use of myths and literary works, mostly Western, is very much part of the narrative. The whole quest,undertaken by Kafka, has its model, the classical Oedipus myth, the curse he wanted to escape. There are other myths discussed in the novel from the beginning of the narrative, for example, Plato's myth of the existence dividing people into three types and the reference to Cassandra.In discussing Kafka's past life, Oshima stretches the conversation to Plato's The Banquet and the "legend" in the "ancient world" of diving people into three types (Murakami, 2003, p.48).

The element of shock and surprise is very much part of the novel for we do not often know for sure what would unfold next, as Nakata says, "I think I'll know it when I get there" (Murakami, 2003, p. 275).Reviewing the novel in question,John Updike extends this uncertainty of what will happen next in the text to the author as well by suggesting that not only do not us, the readers, seem to know what exactly will happen next but the author himself as well (p. 01).Ghosts and other strange creatures give the characters a completely different view of reality around them. It is shocking to see Kafka falling in love with, and making love to a ghost that does not exist in real life. More surprising perhaps is the scene where a slimy creature comes out of from Nakata's mouth in front of the eyes of Hoshino:

He crept silently to the door to Nakata's room and opened it. He switched on the flashlight and played it quickly around the body. That's definitely where the rustling had come from. The beam illuminated a long, pale,thin object that was squirming out of Nakata's mouth. The object reminded Hoshino of a gourd. It was as thick as a man's arm, and though he couldn't tell how long it was, Hoshino guessed that about half of it was out. Its wet body glistened like mucus. Nakata's mouth was stretched wide open like a snake's, to let the thing out. His jaw must have been 
unhinged, it was so wide open. (Murakami, 2003, p.594-95)

In conclusion, then, it can perhaps be claimed that the juxtaposition of the two, the realistic and the speculative or fantastic, in the novel under discussion, foregrounds the idea that theformershould encompass the latter in order to make better sense of our contemporary world.

\section{REFERENCES}

[1] Balderston, D. (2011). Magical Realism. In P. M. Logan, The Encyclopaedia of the Novel. Wiley-Blackwell.

[2] Cuddon, J. A. (1998). Magical Realism. In J. A. Cuddon, The Penguin Dictionary of Literary Terms and Literary Theory. Penguin.

[3] Gioia, T. (n.d.). Kafka on the Shore by Haruki Murakami. Retrieved October 7, 2021, from www.thenewcanon.com website:

http://www.thenewcanon.com/kafka_on_the_shore.html

[4] Meads, J. (n.d.). Into the Labyrinth: The Dream Logic of Kafka on the Shore. Retrieved October 7, 2021, from Steppenwolf.org website: https://www.steppenwolf.org/articles/into-the-labyrinththe-dream-logic-of-kafka-on-the-shore/

[5] Murakami, H (2003). Kafka on the Shore. Translated by Philip Gabriel. Vintage Books, 2005.

[6] Murakami, H. (2014). Questions for Murakami about Kafka on the Shore | Haruki Murakami. Retrieved October 7, 2021, from harukimurakami.com website: https://www.harukimurakami.com/q_and_a/questionsfor-haruki-murakami-about-kafka-on-the-shore

[7] Schlack, J. W. (2021). Currents of destiny run through "Shore." Retrieved October 7, 2021, from Boston.com website:

http://archive.boston.com/ae/books/articles/2005/01/17/c urrents_of_destiny_run_through_shore/

[8] Shakespeare, W. (2010). Hamlet (R. Mighall, Ed.). London: Macmillan Collector's Library.

[9] Shepard, K. (2019). Dreams and Reality in Kafka on the Shore. Retrieved October 7, 2021, from prezi.com website: https://prezi.com/yuudp2ngpnt_/dreams-andreality-in-kafka-on-the-

shore/\#: :text=In\%20Kafka\%20on\%20the $\% 20$ Shore $\% 2$ C\%20characters\%20are\%20linked\%20together\%20not,th e\%20middle $\% 20$ of $\% 20$ a $\% 20$ dream. $\% 20$ Accessed $\% 2010$ $\% 20 \mathrm{Jan} \% 202021$

[10] Sorensen, D. (2007). A Turbulent Decade Remembered: Scenes from the Latin American sixties. Stanford, Calif.: Stanford University Press.

[11] Updike, J. "Subconscious Tunnels". Review of Kafka on the Shore by Haruki Murakami. The New Yorker, 24 Jan 2005.

[12] Warnes, C., \& Sasser, K. A. (2020). Introduction. In C. Warnes (Ed.), Magical Realism and Literature. CUP. doi:https://doi.org/10.1017/9781108551601
[13] Wordsworth, W. (2004). The Prelude: The Four Texts (1798, 1799, 1805, 1850) (J. W. Wordsworth, Ed.). London: Penguin. (Original work published 1850)

[14] Yeung, V. (2017). Stories Within Stories: A Study of Narrative Embedding in Haruki Murakami's 1Q84. Critique: Studies in Contemporary Fiction, 58(4), 426436. doi:https://doi.org/10.1080/00111619.2016.1242474 